\title{
Entrepreneurial Skills in Science through Authentic Learning Strategy: A Panacea for Youth Unemployment in Nigeria
}

\author{
Aina Jacob Kola*, Abdulrahman, Abdulgafar Opeyemi, Abdulwasiu Adebayo Azeez \\ College of Education (T) Lafiagi, Kwara State, Nigeria
}

\author{
${ }^{*}$ Corresponding Author \\ Aina Jacob Kola \\ Article History \\ Received: 08.07.2019 \\ Accepted: 20.07 .2019 \\ Published: 30.07 .2019
}

\begin{abstract}
This is a review paper focusing on the acquisition of entrepreneurial skills in science through the authentic learning strategy to solve the youth unemployment problem in Nigeria. The youth unemployment in Nigeria is observed to be on the increase as indicated by statistics, and the various interventions seem not to be yielding significant results. It is on this background that the paper suggests the entrepreneurial skills through the authentic learning paradigm in Nigeria. The authors asserted that entrepreneurial skills are critical to job creation and self-employability because it enhances creativity and critical thinking skills. The authentic learning is a learning model that connects what the students learned in the classroom to the real-life, challenges and application. Some topics in science among many were identified in this thesis where students could acquire entrepreneurial skills that could make them selfemployed after graduation. The paper identified some implications of the paper and make suggestions for future studies.
\end{abstract}

Keywords: Authentic learning, creativity, critical thinking, entrepreneurial skills, scientific literacy

\section{Introduction}

The youth unemployment rate is increasing in Nigeria at an alarming rate [1]. According to the National Bureau of Statistics [2], $55.4 \%$ of the Nigerian youth were jobless by the third quarter of 2018 as against $52.6 \%$ of 2017 . This is not good for the economic growth of the country [3]. It is not too late for the country to find a lasting solution to the menace. However, the federal government has been struggling to curb this evil of youth unemployment through different social programmes, which seem not to be yielding desired fruits. Among these programmes are the National Directorate of Employment and National Poverty Eradication Programme [3] and recently the N-Power programme. The percentage of jobless youths published by the National Bureau of Statistics [2] shows that NPower programme is not producing a significant result when compared with the 2017 unemployment rate. It thus implies there is the need to apply a better approach that could work for the country.

The youth unemployment issue is a challenge that most developing countries are facing under the current economic circumstances. Even the developed countries are not exempted because they have also not shown a remarkable improvement to this dreadful social problem, although the upsurge is more articulated in the developing nations, most notably Nigeria in particular. With a large number of unemployed youths, Nigeria as a nation will continue to be a confused nation, if she cannot effectively arrest this social menace, which requires deliberate policies of government to apprehend and adequately monitored.

Given this, the need for the science students to acquire entrepreneurial skills through authentic learning paradigm is imperative. Entrepreneurial skills are crucial in science learning because it helps in creating business and self-employed among science students [4]. According to Yusuf, Umar, Arinde and Oladipo [5], the majority of entrepreneurial repertoires can be inculcated into students in chemistry, biology, physics and other. Studies have shown that entrepreneurship education could be an excellent weapon to reduce the unemployment rate among youths in Nigeria [6]. Recently Prabhu [7] asserted that entrepreneurial attitudes are critical keys to increase jobs and businesses for youths in future. The critical challenge in inculcating into the science students the required entrepreneurial skills is the teacher's strategies of teaching. The typical lecture method of teaching among teachers in Nigerian schools today cannot inculcate the skills into the students. Acquiring entrepreneurial skills require effective methods that involve students in creativity and innovation [8]. Therefore, to be able to impart the entrepreneurial skills to science, students require an authentic learning strategy. According to Pearce [9], authentic learning is the one designed to link what students learn in the

Copyright @ 2019: This is an open-access article distributed under the terms of the Creative Commons Attribution license which permits unrestricted use, distribution, and reproduction in any medium for non commercial use (NonCommercial, or CC-BY-NC) provided the original author and source are credited. 
classroom to the real-life issue, problem and applications. Research studies show that what the students learn and the context of learning should mirror the real-life situation $[10,9]$. In an authentic learning context, teacher coaches and scaffolds to enhance students' collaboration in learning and to articulate their understanding $[10,11]$.

Therefore, the focus of this paper is to review studies on how to employ the authentic learning paradigm in acquiring entrepreneurial skills in science to reduce youths' unemployment in Nigeria. The article is divided into different sections for the understanding of different categories of readers, especially those who are not scientifically oriented.

\section{Authentic Learning}

Authentic learning is learning by doing. It is active learning. This, according to Milson [12], is a process dominated with questioning, seeking for information on learning tasks and making conclusions based on the solutions to learning challenges. For learning to be real, it must be student-centred: where students determine and direct the learning by themselves. The tasks must have real-world relevance and also require the production of knowledge instead of reproduction of knowledge [10]. Learning of this kind helps students to use classroom learning to solve the real-world problem outside the class. Students are actively working, participating in discussions, hunting for information, and enjoying the entire process of learning [13]. Authentic learning activities are designed to give the students 'real-world' experiences. Educational researchers have found that students involved in authentic learning are motivated to persevere despite initial disorientation or frustration [14]

Herrington and Kelvin [15] contended that much of the theoretical knowledge taught in most schools cannot be retrieved in real-life because it does not consider the interdependence of situation and cognition. For this knowledge to be relevant and retrievable in real-life, Herrington and Kelvin made a case for authentic learning with the nine fundamental elements. The elements are authentic contexts, authentic activities, expert performances, multiple roles and perspectives, collaborative construction of knowledge, reflection, articulation, coaching and scaffolding, and authentic assessment.

\section{Entrepreneurial Skills}

According to Onuma [16], the present youth unemployment challenge facing Nigeria has been traced to the lack of entrepreneurial skills of students. According to Martin and lucu [17], entrepreneurship education is to develop students' entrepreneurial skills and attitudes. The purpose of entrepreneurship education in Nigeria is to inculcate skills for job creation. Teachers are vital to entrepreneurship education because they are the facilitators and multipliers of knowledge which help students acquire the entrepreneurial skills [8]. According to Karimi, Biemans, Lans and Mulder [18], entrepreneurship is essential to the increase of economic efficiencies, market innovation, creation of new jobs and raising of employment level. Entrepreneurship is a powerful instrument which creates jobs and enhances economic power in the labour market [19]. Entrepreneurship education helps students to develop skills, knowledge and attitudes needed to achieve goals they set for themselves [20]. An effective teaching method is required to acquire entrepreneurial skills García, Ward, Hernández \& Florez [8]. The teaching of entrepreneurship education is required to enhance students' creativity in job creation [8].

The entrepreneurship education is in vogue, mostly in tertiary institutions of the world. The reason for this is to equip the students with the skills to be self-employed after graduation. However, the skills for self-employed have not been fully implemented for science students in many Nigerian schools as it is partially done in technical education.

There are many areas science students can learn skills that could be of great benefits to make them self-employed after graduation. The skills could be employed to start a small scale business instead of seeking for non-existing white collar jobs. The small scale business could evolve into industries and company where more hands could be employed with funds from the government and banking sector. In chemistry, few of these areas the students could leverage on are cosmetic, beverages, dye, soap and detergent, perfume and others. For biology, we have but not limited to the fishery, horticulture, honey production, animal rearing, textiles, food processing. Physics has areas like ceramic production, Forensic, repairing electronic devices, fixing home electrical devices, automobile electrical, mobile phone repairing, telecommunication devices and many more. The skills required in some of the areas mentioned above are not limited to only one science subject. For instance, the skill in forensic science could be developed in biology and chemistry, not only in physics; it all depends on the pedagogical knowledge of the teacher.

\section{Developing Entrepreneurial Skills through Authentic Learning}

The authentic learning paradigm is a student-centred mode of teaching guided by the nine elements, as mentioned earlier [10]. For science teachers to ensure the achievement of entrepreneurial skills and fully imparted to the students, the nine elements must be applied to the teaching where practicable.

The science classroom should not only be filled with textbooks and notebooks from the teachers instead of learning materials that make learning resemble the practice in the real-life situation. For instance, learning saponification topic in chemistry could be taught in a way to resemble how it is being used in the industries for soap making. During the learning period, students should be allowed to search for information from various sources on saponification and ask questions. The students should have control over what and how they learn. The students are to be critical thinkers who identify the premise and able to make logical conclusions. According to Herr [21], critical thinkers break arguments into basic statements and draw logical conclusions. 
The learning activities or tasks should reflect the kind of activities that people do in the real world. The tasks must be illdefined and promote exploration where students find as well as solve the problems. For example, in physics, where students learn topic like semiconductor and related topics in solid-state physics can help them garner skills for ceramic production. This is very simple; it all depends on how the teachers handle the teaching. In authentic learning, such topics are presented and taught in a way that the students will be inquisitive. The teacher does not give notes to the students for memorisation but lets them make mistakes and correct themselves. The learning situation where the learning task is given to students in a well-defined step by step procedure does not help to learn it only aids memorisation. For a teacher to make learning contexts and activities resemble the real-life situation in most cases requires the use of technologies. Thus, the students are familiar with the use of technologies as against the conventional method of teaching with the textbooks and teacher's talking.

The learning tasks must be such that encourage collaboration between students, teacher, and students. Students should be allowed to collaborate not only cooperate. As already discussed, collaboration is an essential element of authentic learning critical to scientific inquiry. Collaboration promotes dialogical argumentation, which is crucial to modern science learning. Sampson, Enderle, and Grooms [22] argued that teachers need to provide students with more opportunities to craft scientific arguments and participate in discussions that require them to support and challenge claims based on evidence. A genuine collaboration for learning requires the students to go online to seek information to refute some proposition during an argument. Authentic learning does not support acceptance of any information without a thorough investigation or proof.

It is an essential part of the authentic learning for the teacher not to see himself or herself as the sole authority in science class but to coach and scaffold. The teacher should also act as a learner but guide the students where needed and withdraw for the students to learn by themselves. It is not about the covering of the syllabus but allows the students to reflect both in and on what they learned [10]. This implies the student should be able to revisit the learning tasks any time. There should be opportunities for students to articulate their understanding. The articulation enables students to verbalise what they learned either in a collaborative group or through the presentation to the class. Reflection means both the students and the teachers should be able to retrieve the learning information at a later time. Retrieving information is best done with the help of the technologies.

The students must learn through various resources. Science learning should not only be through textbooks and teachers. The inclusion of technologies in learning makes it easy and authentic. Different mobile technologies promote authentic learning that can be used in science classes. Through these, students can have access to different databases apart from the familiar Google search engine. The community learning paradigm is in vogue in many developed countries which make learning authentic. For instance, field trip and expert performance are germane to science education authentic learning. It should be part of a learning task to bring professional experts to science class for the students to learn from them. For example, biology students can learn fishery and plant anatomy by bringing into the class experts from the fish industry and a horticulturist. Otherwise, video movies of such expert could be brought to the class to learn and ask questions.

Given the authentic learning in science education as discussed above, the students will no longer rely on memorisation, but learn to "do" science. The authentic learning in science, where students learned and applied the knowledge outside the classroom is critical to science. These students will have technical skills and could utilise anywhere in life. Most of these students would be able to access email, Skype, blog, search databases; they would be able to use Microsoft PowerPoint and Spreadsheet and other computer application for learning.

In light of the preceding, the joblessness as a current challenge in the country could be solved because it is an evil affecting the growth of the nation. According to Longe [23], graduate unemployment has been a socio-economic challenge for the nation. Uddin and Uddin [24] have argued that unemployment causes a decline in quality of life and job security in Nigeria. It was asserted by Emeh [1] that the skills could have been an antidote to unemployment have not been taken seriously in the Nigerian educational system, but academic excellence without skills. For Surajo and Karim [3], the unemployment issue in Nigeria is not only a problem for the youth but a stiff challenge to the sustainable growth and development of the nation. Table-1 adopted from the National Bureau of Statistics compared the unemployment rate between 2017and 2018 in Nigeria.

Table-1: Unemployment Rate in Nigeria between 2017 and 2018

\begin{tabular}{|l|l|l|l|l|}
\hline Period & $\begin{array}{l}\text { Unemployment Rate } \\
(\%)\end{array}$ & $\begin{array}{l}\text { Rate of Quarterly } \\
\text { Change (\%) }\end{array}$ & $\begin{array}{l}\text { Post-secondary or Graduate } \\
\text { Unemployment Rate (\%) }\end{array}$ & $\begin{array}{l}\text { Rate of Quarterly } \\
\text { Change (\%) }\end{array}$ \\
\hline $2017 q 1$ & 14.44 & 0.21 & 16.66 & -7.02 \\
\hline q2 & 16.18 & 1.74 & 27.96 & 11.3 \\
\hline q3 & 18.8 & 2.62 & 31.78 & 3.82 \\
\hline q4 & 20.42 & 1.62 & 25.65 & $-6-13$ \\
\hline $2018 \mathrm{q} 1$ & 21.83 & 1.41 & 30.3 & 4.65 \\
\hline q2 & 22.73 & 0.9 & 32.45 & 2.15 \\
\hline q3 & 23.13 & 0.4 & 29.75 & -2.7 \\
\hline
\end{tabular}

Source: National Bureau of Statistics, Nigeria 
The table indicates the highest unemployment rate among the post-secondary or graduate with an average value of $30.8 \%$ in 2018. However, with entrepreneurial skills acquired through authentic learning, there could be a positive change in the data that would be collected in the subsequent year.

The challenges the country is facing due to unemployment are significant as many of the youths are employed as political thugs during political rally/campaign and also at the time of crisis [25]. It is therefore critical to do everything possible to get the Nigerian youths gainfully employed through entrepreneurial skills to abate the menace. Many countries of the world like Malaysia, who had a meagre unemployment rate still cherished the acquisition of entrepreneurial skills and attitude through viable entrepreneurship education [26]. The evolvement of entrepreneurial skills through authentic learning has some implications that must be discussed.

\section{The Implications}

The paper implies the scientific literacy of both the teachers and the students. Scientific literacy is a concept that does not have a consensus definition, but scholars concurred it is using scientific understanding and knowledge to solve a practical problem and make a personal decision in society [27]. This paper will enhance both teachers and students abilities to solving problems creatively, thinking critically, working cooperatively in teams, using technology effectively, and valuing life-long learning [28]. Creating jobs depends much on the creativity and the critical thinking ability of an individual amid abundant natural resources in Nigeria. According to Siarova, Sternadel and Szőnyi [29], critical thinking is one major element of scientific literacy, a critical repertoire giving individuals the ability to function as a responsible citizen in a dynamic world.

The security situation in Nigeria is a serious challenge to every citizen residing in the country [30] primarily due to the high rate of youth unemployment. It thus implies that this article could significantly impact the security situation of the country as youths learned to possess entrepreneurial skills for self-employment. A scientifically literate graduate would be able to make decisions that will not jeopardise him/her and the nation. This will not be like the case of indoctrinating youths on religion issue leading to Boko Haram insurgency in the North and ethnicity as the case of the East and South West regions of the country.

\section{Suggestion for Further Study}

Given the several germane points raised in this paper as regards youth unemployment in Nigeria and the identified implications of the paper, the following suggestions are critical:

- More empirical studies are required on the veracity of using authentic learning strategy to acquire entrepreneurial skills in science.

- Scientific literacy of both the science teachers and students should be investigated in both secondary and post-secondary schools in Nigeria.

\section{References}

1. Emeh, I. E. J. (2012). Tackling youth unemployment in Nigeria; the Lagos state development and empowerment Programmes Initiatives. Afro Asian Journal of Social Sciences, 3(3.4), 2229-5313.

2. National Bureau of Statistics. (2018). Labour Force Statistics Volume 1: Unemployment and Underemployment Report (Q2017-Q3 2018). Abuja, Nigeria: NBS.

3. Surajo, A. Z., \& Karim, A. H. M. Z. (2016). Youth unemployment and poverty in Nigeria: a threat to sustainable growth and development. International Journal of Scientific Research and Management (IJSRM), 4(11), 4919-4928

4. Sanchez, J. C., Ward, A., Hernández, B., \& Florez, J. (2017). Entrepreneurship education: State of the art Propósitos y Representaciones, 5(2), 401-473.

5. Yusuf, N. B. Umar, A. G., Arinde, O. O., \& Oladipo, F. T. (2019). Attitude of college of education science students towards entrepreneurial skills acquisition. International Journal of Economics and Business, 3(2) 232-238.

6. Araba, S. O. (2012). Entrepreneurial education as a tool for reducing unemployment in Nigeria. (Master thesis, Babcock University, Nigeria) Retrieved June 14, 2018, from https://www.academia.edu/2047944/Entrepreneurial_Education_as_a_tool_for_reducing_Unemployment_in_Nigeria

7. Prabhu, J. J. (2019). A study of entrepreneurship education and entrepreneurial attitude in Malaysia- The relationship between employment and unemployment analysis. International Journal of Trend in Scientific Research and Development (IJTSRD), 3(3), 840-842

8. García, J. C. S., Ward, A., Hernández, B., \& Florez, J. L. (2017). Entrepreneurship education: State of the art. Propósitos y Representaciones, 5(2). In press. http://dx.doi.org/10.20511/pyr2017.v5n2.190

9. Pearce, S (2016). Authentic learning: what, why and how? Management strategies for classroom, ACEL Inspiring Educational Leaders, 2016(10). Retrieved June 04, 2019 from www.acel.org.au

10. Herrington, J., Reeves, T. C., \& Oliver, R. (2010). A guide to authentic e-learning. New York: Routledge.

11. Kola, A. J. (2017). The Physics Authentic Learning Experience through the Peer Instruction. LAP LAMBERT Academic Publishing.

12. Milson, A. J. (2002). The Internet and inquiry learning: Integrating medium and method in a sixth grade social studies classroom. Theory \& Research in Social Education, 30(3), 330-353. 
13. Mims, C. (2003). Authentic learning: A practical introduction \& guide for implementation Meridian. A Middle School Computer Technologies School, 6(1), 1-12.

14. Lombardi, M. M., \& Oblinger, D. G. (2007). Approaches that work: How authentic learning is transforming higher education. EDUCAUSE Learning Initiative (ELI) Paper, 5.

15. Herrington, J., \& Kelvin, L. (2007). Authentic learning supported by technology: 10 suggestions and cases of integration in classrooms. Educational Media International, 44(3), 219-236.

16. Onuma, N. (2016). Entrepreneurship education in Nigerian tertiary institutions: a remedy to graduates unemployment. British Journal of Education, 4(5), 16-28

17. Martin, C., \& lucu, R. B. (2014). Teaching entrepreneurship to educational sciences students. Procedia-Social and Behavioral Sciences, 116, 4397-4400.

18. Karimi, S., Biemans, H., Lans, T., Mulder, M., \& Chizari, M. (2012). The Role of Entrepreneurship Education in Developing Students' Entrepreneurial Intentions. Proceedings of WICaNeM 2012, The 10th Wageningen International Conference on Chain and Network Science, Wageningen University, Wageningen, The Netherlands, 22.

19. Byun, C., Sung, C. S., Park, J. Y., Choi, D. S. (2018). A Study on the effectiveness of entrepreneurship education programs in higher education institutions: a case study of Korean graduate programs. Journal of Open Innovations: Technology, Market, and Complexity, 4(26), 1-14.

20. Minna, H. (2018). Principals promoting entrepreneurship education: the relationships between development activities and school practises. Journal of Entrepreneurship Education, 21(2), 1-19.

21. Herr, N. (2007). Elements of critical thinking. The sourcebook for teaching science. San Francisco. CA: John Wiley Publisher.

22. Sampson, V., Enderle, P., \& Grooms, J. (2013). Argumentation in science education. The Science Teacher, 30-33.

23. Longe, O. (2017). Graduate unemployment in Nigeria: Causes, consequences and remediable approaches. American International Journal of Contemporary Research, 7(4), 63-73.

24. Uddin, P. S. O., \& Uddin, O. O. (2013). Causes, effects and solutions to youth unemployment problems in Nigeria. Journal of Emerging Trends in Economics and Management Sciences (JETEMS) 4(4), 397-402.

25. Obayori, J. B., Osai, V. A., Ahmodu, K. O., \& Maeba, L. S. (2018). Security and terrorism challenges in Nigeria: Causes, consequences and the way forward. International Journal of Advanced Studies in Economics and Public Sector Management, 6(2), 101-108.

26. Prabhu, A., \& Venkata Ramanan, M. (2018). Emission and performance analysis of pentanol-diesel blends in unmodified diesel engine. International Journal of Ambient Energy, 1-4.

27. Ogunkola, B. J. (2013). Scientific literacy: Conceptual overview, importance and strategies for improvement. Journal of Educational and Social Research, 3(1), 265-274.

28. National Research Council. (1996). National science education standards. National Academies Press.

29. Siarova, H., Sternadel, D., \& Szőnyi, E. (2019). Research for CULT Committee - Science and Scientific Literacy as an Educational Challenge, European Parliament, Policy Department for Structural and Cohesion Policies, Brussels.

30. Achumba, I. C., Ighomereho, O. S., \& Akpor-Robaro, M. O. M. (2013). Security challenges in Nigeria and the implications for business activities and sustainable development. Journal of Economics and Sustainable Development, 4(2), 79-99. 